\title{
Hygroscopic and chemical characterisation of Po Valley aerosol
}

\author{
J. Bialek ${ }^{1}$, M. Dall Osto ${ }^{1}$, P. Vaattovaara ${ }^{2}$, S. Decesari ${ }^{3}$, J. Ovadnevaite ${ }^{1}$, A. Laaksonen ${ }^{4}$, and C. O'Dowd ${ }^{1}$ \\ ${ }^{1}$ School of Physics and Centre for Climate and Air Pollution Studies, National University of Ireland Galway, University Road, \\ Galway, Ireland \\ ${ }^{2}$ University of Eastern Finland, Department of Applied Physics, 70210, Kuopio, Finland \\ ${ }^{3}$ Institute of Atmospheric Sciences and Climate (ISAC) of the Italian National Research Council (CNR), via P. Gobetti 101, \\ 40129 Bologna, Italy \\ ${ }^{4}$ Finnish Meteorological Institute, Erik Palménin aukio 1. 00560 Helsinki, Finland \\ Correspondence to: J. Bialek (jakub.bialek@nuigalway.ie)
}

Received: 15 January 2013 - Published in Atmos. Chem. Phys. Discuss.: 4 February 2013

Revised: 19 December 2013 - Accepted: 20 December 2013 - Published: 12 February 2014

\begin{abstract}
Continental summer-time aerosol in the Italian Po Valley was characterised in terms of hygroscopic properties and the influence of chemical composition therein. Additionally, the ethanol affinity of particles was analysed. The campaign-average minima in hygroscopic growth factors (HGFs, at $90 \%$ relative humidity) occurred just before and during sunrise from 03:00 to 06:00 LT (all data are reported in the local time), but, more generally, the hygroscopicity during the whole night is very low, particularly in the smaller particle sizes. The average HGFs recorded during the low HGF period were in a range from 1.18 (for the smallest, $35 \mathrm{~nm}$ particles) to 1.38 (for the largest, $165 \mathrm{~nm}$ particles). During the day, the HGF gradually increased to achieve maximum values in the early afternoon hours 12:0015:00, reaching 1.32 for $35 \mathrm{~nm}$ particles and 1.46 for $165 \mathrm{~nm}$ particles. Two contrasting case scenarios were encountered during the measurement period: Case 1 was associated with westerly air flow moving at a moderate pace and Case 2 was associated with more stagnant, slower moving air from the north-easterly sector. Case 1 exhibited weak diurnal temporal patterns, with no distinct maximum or minimum in HGF or chemical composition, and was associated with moderate non-refractory aerosol mass concentrations (for $50 \%$ size cut at $1 \mu$ ) of the order of $4.5 \mu \mathrm{g} \mathrm{m}^{-3}$. For Case 1 , organics contributed typically $50 \%$ of the mass. Case 2 was characterised by $>9.5 \mu \mathrm{g} \mathrm{m}^{-3}$ total non-refractory mass $(<1 \mu)$ in the early morning hours (04:00), decreasing to $\sim 3 \mu \mathrm{g} \mathrm{m}^{-3}$ by late morning (10:00) and exhibited strong diurnal changes in chemical composition, particularly in nitrate mass but also in total organic mass concentrations. Specifically, the con-
\end{abstract}

centrations of nitrate peaked at night-time, along with the concentrations of hydrocarbon-like organic aerosol (HOA) and of semi-volatile oxygenated organic aerosol (SV-OOA). In general, organic growth factors (OGFs) followed a trend which was opposed to HGF and also to the total organic mass as measured by the aerosol mass spectrometer. The analysis of the HGF probability distribution function (PDF) reveals an existence of a predominant "more hygroscopic" $(\mathrm{MH})$ mode with HGF of 1.5 around noon, and two additional modes: one with a "less hygroscopic" (LH) HGF of 1.26, and another with a "barely hygroscopic" (BH) mode of 1.05. Particles sized $165 \mathrm{~nm}$ exhibited moderate diurnal variability in HGF, ranging from $80 \%$ at night to $95 \%$ of "more hygroscopic" growth factors (i.e. HGFs 1.35-1.9) around noon. The diurnal changes in HGF progressively became enhanced with decreasing particle size, decreasing from $95 \%$ "more hygroscopic" growth factor fraction at noon to $10 \%$ fraction at midnight, while the "less hygroscopic" growth factor fraction (1.13-1.34) increased from $5 \%$ at noon to $>60 \%$ and the "barely hygroscopic" growth factor fraction (1.1-1.2) increased from less than $2 \%$ at noon to $30 \%$ at midnight. Surprisingly, the lowest HGFs occurred for the period when nitrate mass reached peak concentrations (Case 2). We hypothesised that the low HGFs of nitrate-containing particles can be explained by a) an organic coating suppressing the wateruptake, and/or by b) the existence of nitrates in a less hygroscopic state, e.g. as organic nitrates. The latter hypothesis allows us to explain also the reduced OGFs observed during the early morning hours (before dawn) when nitrate concentrations peaked, based on the evidence that organic nitrates 
have significant lower ethanol affinity than other SV-OOA compounds.

\section{Introduction}

Light scattering by aerosol particles affects climate forcing through the direct backscattering of incoming solar radiation back into space. The scattering strongly depends on the aerosol's ability to absorb water (hygroscopicity), which in turn, determines the particle's ambient size under a given humidity regime. Additionally, hygroscopicity can determine the particle's ability to act as a cloud condensation nucleus CCN (Hänel, 1976; Hegg et al., 1993; Svenningsson et al., 1994; McInnes et al., 1998; McFiggans et al., 2006). The aerosol's hygroscopicity may be expressed as a diameterbased hygroscopic growth factor (HGF, Dennis, 1960) and usually is defined as the ratio of the wet particle diameter at a given relative humidity (usually $90 \%$ ) to the dry particle diameter at a given relative humidity (usually $20 \%$ ). HGFs for common atmospheric inorganic salts such as ammonium sulfate and sea salt are 1.8 and 2.2, respectively, while oxidised organic aerosol possesses lower HGFs and freshly emitted non-oxidised primary organics have a HGF close to 1 .

Primary organic aerosols emitted directly into the atmosphere undergo transformation during transport due to oxidation and multi-phase chemical processes (Rogge et al., 1993; Kittelson, 1998; Kupiainen and Klimont, 2007; Allan et al., 2010) while secondary material is added both as additional, condensable mass to existing particles, and through the modification of existing aerosol matter (Jimenez et al., 2009). The secondary formation or modification of condensed matter on pre-existing particles may dramatically change their hygroscopic behaviour (Saxena et al., 1995). Particles, previously hydrophobic, but coated with oxidised organics can start to exhibit activity as $\mathrm{CCN}$ and participate in cloud formation. The life-cycle of secondarily formed organic aerosol (SOA), however, is not well understood because of myriads of possible chemical compounds taking part in the creation of this type of the aerosol. This is in contrast with the life cycle of inorganic compounds such as sulfates and nitrates whose properties and sources are well-characterised (Ansari and Pandis, 1999). Additionally, understanding the mixing state of organics and inorganics may be of great importance in describing the overall impact of anthropogenic pollution on the climate.

Recent technological developments have advanced our capability to chemically characterise atmospheric aerosols, particularly so with advances in aerosol mass spectrometry. Aerosol mass spectrometry, in conjunction with statistical analysis tools such as positive matrix factorisation (PMF) has improved the capability to distinguish between SOA and primary organic aerosol (POA), and, in turn, local and regional sources of OA (Paatero and Tapper, 1994; Schauer et al., 1996; Lee et al., 1999; Zhang et al., 2005; Lanz et al., 2007). Many laboratory studies have been performed on the SOA formation using the hygroscopic tandem differential mobility analyser (HTDMA) and aerosol mass spectrometric techniques coupled together (Baltensperger et al., 2005; $\mathrm{Ng}$ et al., 2006; Meyer et al., 2009; Duplissy et al., 2011; Massoli et al., 2011). In general, all SOA is found to be slightly hygroscopic, with water uptake less than that of typical inorganic aerosol substances. HGF values reported in the laboratory studies ranged from 1.05 (for the fresh SOA) to 1.2 (for highly oxidised SOA). The aerosol water uptake increases with time early in the experiments for the cycloalkane SOA, but decreases with time for the biogenic SOA (Varutbangkul et al., 2006). This behaviour could indicate competing effects between the formation of more highly oxidised polar compounds (more hygroscopic), and formation of longer-chained oligomers (less hygroscopic). All SOA also exhibit a smooth water uptake with RH (relative humidity) with no deliquescence or efflorescence (Varutbangkul et al., 2006). However, field applications of HTDMA and aerosol mass spectrometer (AMS) running in parallel have been rather less abundant so far (Gasparini et al., 2004; Mochida et al., 2008; Jurányi et al., 2010; Jones et al., 2011, Raatikainen et al., 2010). Additionally, organic tandem differential mobility analyser (OTDMA) and aerosol mass spectrometric have been successfully used in parallel under field conditions (Jimenez et al., 2009; Raatikainen et al., 2010).

This study presents results from the deployment of an HTDMA, OTDMA and an AMS to characterise continental aerosol properties during the 2009 EUCAARI intensive field campaign in the rural region of the Po Valley, which is strongly influenced by urban and transport generated aerosol pollution.

\section{Methods and instrumentation}

The HTDMA configuration used during the campaign consisted of two Hauke-type differential mobility analysers (DMAs), an aerosol conditioner (heated Gore-Tex humidifier) and a condensation particle counter (CPC model 3772) with sample flow of $1 \mathrm{~L} \mathrm{~min}^{-1}$. RH was controlled by a PID (proportional, integral and derivative) feedback loop using the Rotronic RH probes and an Edgetech Dewmaster dewpoint chilled mirror sensor. The aerosol sample was given charge equilibrium by a Thermo Systems Inc. (TSI) ${ }^{85} \mathrm{Kr}$ aerosol neutraliser operating at activity of $10 \mathrm{mCi}$. The electrical mobility sizes measured were $35,50,75,110$, and $165 \mathrm{~nm}$. The scan length for each size was set to $180 \mathrm{~s}$; full scan cycle was taking $15 \mathrm{~min}$ and $50 \mathrm{~s}$.

The main principle of operation of the DMA (Knutson and Whitby, 1975; Liu et al., 1978) is to select a narrow band of an aerosol size distribution by applying high voltage to its central rod thus selecting particles with a particular electrical mobility. In this way, a monodisperse aerosol distribution is allowed to pass through the instrument. For the 
HTDMA, two DMA are positioned on either side of a humidification conditioner, allowing the humidification of a selected dry particle size followed by characterisation of its humidified size. Since the dry diameter of aerosol is well known (aerosol is dried with 50-tube Nafion dryer down to $5 \% \mathrm{RH}$ prior entering first DMA) by measuring the size of particles exiting second DMA one can calculate HGF. The sizing of the wet aerosol is achieved by scanning the electrical mobility of the humidified particles and particles exiting second DMA are counted by the CPC. Sheath to aerosol flow ratio is maintained at $1: 9$ by use of critical orifices on both DMAs' sheath flow pumps. In order to be able to dry calibrate the HTDMA, a two-way valve is fitted before the dryer to bypass it as needed. The whole setup is controlled by the PC which acts as PID controller for the humidifier and a data processor and logger.

An inversion algorithm has to be applied to the measurement distribution function (MDF) of TDMA measurements to retrieve the GF-PDF's (growth factor - probability distribution function) correct shape, to determine the mean GF of the sample and to provide the number fractions of particles in different GF ranges. Details of the kernel calibration, data inversion, and TDMA forward function are described by Gysel et al. (2009).

The working principle of the UFO-TDMA (ultrafine organic tandem differential mobility analyser, called OTDMA later in this manuscript) is similar to the HTDMA, except that ethanol is the working fluid rather than water and the particles are brought to a selected sub-saturated ethanol vapour environment where they can grow to a new size in accordance to their composition and size (Joutsensaari et al., 2001; Vaattovaara et al., 2005). The ratio between the measured size in the second DMA and the size selected in the first DMA is called ethanol growth factor or organic growth factor (OGF, used in this manuscript). Depending on the chemical composition of the particles, different amounts of ethanol are taken up at a given saturation ratio by the particles. We applied the OTDMA to $50 \mathrm{~nm}$ particles. The error estimate of the OGF values is smaller than 0.01 for $50 \mathrm{~nm}$ particles. Uncertainties of growth factors were estimated for the $50 \mathrm{~nm}$ particle size based on a relative growth factor change between the consecutive dry size laboratory measurements for different compounds (Vaattovaara et al., 2005). The estimation was carried out based on the $0.1 \mathrm{~nm}$ uncertainty in the particle diameter measurements, i.e. 0.1/50). The saturation ratio was $81 \pm 2 \%$. The $0.1 \mathrm{~nm}$ uncertainties are related to continuous consecutive measurements in the laboratory conditions (e.g. when $10 \mathrm{~nm}$ are measured continuously, the difference in the grown size is $0.1 \mathrm{~nm}$ between the measurements), thus representing a geometric standard deviation. The absolute errors in particle size should be on the same level as in other TDMAs.

Inorganic particles such as sodium chloride and the ammonium sulfate do not grow (i.e. OGF is 1) in the sub-saturated ethanol vapour (the OTDMA saturation was $82-84 \%$ ), while pure ammonium bisulfate or particles containing ammonium bisulfate and a sulfuric acid with sulfuric acid mass fraction of up to $33 \%$ grow in sub-saturated ethanol vapour when the dry particle diameter is $10 \mathrm{~nm}$ or smaller and $S<84 \%$ (Vaattovaara et al., 2005). The $50 \mathrm{~nm}$ ammonium bisulfate particles exhibit OGF values of 1.02-1.03 at a saturation of $81-83 \%$. (Vaattovaara et al., 2005). However, this growth is a minor fraction compared to the total growth factor value observed in this study. More importantly, sulfuric acid or ammonium bisulfate are already neutralised to less acidic form in atmospheric $50 \mathrm{~nm}$ size particles and thus their OGF behave like ammonium sulfate in atmospheric conditions. However, particles composed of biogenic organics (e.g. citric acid or tartaric acid) do grow (i.e. OGF is clearly over 1; Vaattovaara et al., 2005). Generally, moderately oxidised organic particles do grow very well (Vaattovaara et al., 2009). It is also notable that if organic compounds are composed of non-polar organic compounds (Tiitta et al., 2010) or if they are highly aged (Vaattovaara et al., 2009), they do not grow so well either. The OTDMA and the HTDMA provide complementary information about the affinity of inorganics and organics to ethanol and water, which can be used to indirectly probe the composition change of the particle phase (Vaattovaara et al., 2009). So far, they have been successfully used in parallel to study the composition and diurnal cycles of 50-100 nm particles in different field conditions (Boy et al., 2004; Petäjä et al., 2005; Tiitta et al., 2010).

Aerosol chemical composition was measured with the Aerodyne Research Inc. high resolution, time-of-flight aerosol mass spectrometer (HR-ToF-AMS) which provides real-time size resolved composition analysis of volatile and semi-volatile particulate matter. The combination of size and chemical analysis of sub-micron aerosol mass loading with fast time resolution makes the AMS unique. The theory of operation is described in Jayne et al. (2000), Jimenez et al. (2003) and Jimenez et al. (2006). In summary, the AMS quantifies non-refractory aerosol chemical composition, covering major inorganic species such as ammonium, sulfate, nitrate, etc., and organic species. The AMS detects composition quantitatively by combining thermal vaporisation and electron ionisation. For mass concentration calculations, an empirical particle collection efficiency (CE) factor of 0.5 was used, already widely found to be representative for ambient particles in many AMS studies (Jayne et al., 2000; Canagaratna et al., 2007, Middlebrook et al., 2012) and the value of 0.5 was further validated by good inter-comparison with offline ion mass concentration measurements obtained during the field study. The analysis was performed using the ion chromatography on the Berner impactor samples (lumped stages of up to $1.2 \mu \mathrm{m})$. The correlation measured was as follows: $r^{2}=0.64$ for $\mathrm{SO}_{4}, 0.67$ for $\mathrm{NO}_{3}, 0.58$ for $\mathrm{NH}_{4}$ and 0.65 for $\mathrm{Cl}$.

Factor analysis of AMS data enables differentiation between different OA types and determination of the oxygen content in OA. POA from fossil fuel combustion and 
other hydrocarbon-like OA (HOA) and biomass-burning OA (BBOA) can be distinguished as an oxygenated organic aerosol (OOA), low-volatility OOA (LV-OOA), semi-volatile OOA (SV-OOA) and cooking OA (COA). PMF (Ulbrich et al., 2009) was run on both low and high resolution AMS organic data with a focus on a five-factor solution. The five factors are OOA1 (local), OOA2 (regional), HOA, COA and SV-OOA. Although the PMF analysis was performed for the duration of the campaign for 1-7 factors, it was found that the PMF solutions with factor numbers greater than five provided no new meaningful information and instead resulted in a splitting of the existing factors. The five-factor solution was thus chosen as the optimal solution following a number of considerations, including correlations between the chosen AMS PMF solution and measurements taken using the other techniques, specifically with aerosol time of flight mass spectrometer data (see methodology used, for example, in Dall'Osto et al., 2012). In this work all data are reported in the local time.

\section{Measurements location}

Measurements were undertaken at San Pietro Capofiume (SPC), situated near Bologna, Emilia-Romagna, Italy (geographical coordinates: $44^{\circ} 39^{\prime} 0^{\prime \prime}$ North, $11^{\circ} 38^{\prime} 0^{\prime \prime}$ East, Fig. 1). The geographical location of the SPC site makes it ideally situated for anthropogenic pollutions studies. Both rural and urban influences can be investigated and both sources of aerosol can be elucidated. SPC is situated close to two major Po Valley cities: Bologna $25 \mathrm{~km}$ to the South, with over 300000 inhabitants, heavy industry, and a major transportation hub; and Ferrara $20 \mathrm{~km}$ to the north, with 130000 inhabitants and food and machinery industry. The site itself is surrounded by wheat and corn fields with a small food processing plant $800 \mathrm{~m}$ south-east from the station. During the campaign, intensive harvesting activities were performed around the site. This region of Italy is characterized by a dense network of primary and secondary roads. San Pietro Capofiume is situated close to main motorways: A14 Bologna - Rimini $22 \mathrm{~km}$ from the site to the South, part of motorway system connecting Milano and Adriatic coast, A13 connecting Bologna - Vanezia, $11 \mathrm{~km}$ from the site to the west, and motorway link from A13 to the Adriatic coast, $16 \mathrm{~km}$ to the north. Additionally, long range transport and aged aerosol from distant pollution sources along river Po can be investigated.

\section{Meteorological overview}

Meteorological conditions in San Pietro Capofiume (SPC) were characterised by weak wind speed, with prevailing $\mathrm{E}$ to SE wind direction for $32 \%$ of the time with ESE being the most frequent sector. The strongest wind speeds registered for this sector were $5-6 \mathrm{~m} \mathrm{~s}^{-1}$ but only for a fraction of time
$(<1 \%)$. The mean wind speed for this sector was $3.5 \mathrm{~m} \mathrm{~s}^{-1}$. Highest wind speeds were recorded for the W-WNW sector with maximum around $14 \mathrm{~m} \mathrm{~s}^{-1}$ for a short duration of time $(<1 \%)$. Mean wind speed for this sector was $6.3 \mathrm{~m} \mathrm{~s}^{-1}$. Calm conditions $\left(0-1 \mathrm{~m} \mathrm{~s}^{-1}\right)$ amounted to $17 \%$ of total duration of campaign. The highest temperature recorded for the duration of the campaign was $32{ }^{\circ} \mathrm{C}$ on 3 July, lowest temperature recorded was $14.5^{\circ} \mathrm{C}$ on 11 July.

Air-mass back trajectories were classified into six clusters, but essentially we discriminated between two generic types called "West", reflecting a longer range transport from western Europe and the Atlantic (two different zones, West 1 "Western Europe" and West 2 "Atlantic"), and types called "PoV", describing a weaker circulation with more regional (Po Valley) component. The analysis of shorter $(24 \mathrm{~h})$ back trajectories provides essentially the same results. Data for air mass classification were sourced from HYSPLIT 24 and $48 \mathrm{~h}$ back trajectories with a $500 \mathrm{~m}$ a.s.l. endpoint. Local meteorological measurements were recorded at the station. Radio soundings at SPC are available at http://weather.uwyo. edu/upperair/sounding.html, station code: 16144. Subjective classification of synoptic weather conditions was done using the METEOSAT satellite images. Deep convective systems affected the circulation in the Po Valley sector around SPC on several days bringing strong thundery showers to the site. The circulation driven by these systems cannot be captured by the back-trajectory analysis. Convective rainfalls were registered on 5, 7, 9 and 10 July. The highest rainfall was registered on 9 June with $14 \mathrm{~mm}$ falling in $30 \mathrm{~min}$.

\subsection{Meteorological overview for the chosen cases}

\subsubsection{Case 1: 7 July 2009 12:00 to 9 July 2009 12:00}

In the afternoon of 7 July the air mass was of PoV type, captured well by the back trajectories. Showers were recorded at SPC from the precipitating systems travelling eastward over the Po Valley. In the period of 8-9 (until midday) July, "West 1 " or "West 2" circulations were recorded and westerly winds captured by the ground sensors and radio soundings at all heights. Clear sky turned to scattered clouds later in this period.

\subsubsection{Case 2: 9 July 2009 12:00 to 11 July 2009 12:00}

From the afternoon of 9 to 11 July lowest $T_{\max }$ (the maximum temperature of the day) of the campaign was recorded. The $T_{\min }$ (the minimum temperature of the day) was progressively decreasing and it became more humid. Back trajectories were of types PoV, but actually the circulation was complex: westerlies persisted at the top of the boundary layer (1500 m a.s.1.), and easterly winds (from the Adriatic) intensified at ground level at the end of this period, especially on 11 July. Precipitating systems developed on the Apennines on 9 July around midday, bringing a lot of rain to Bologna 


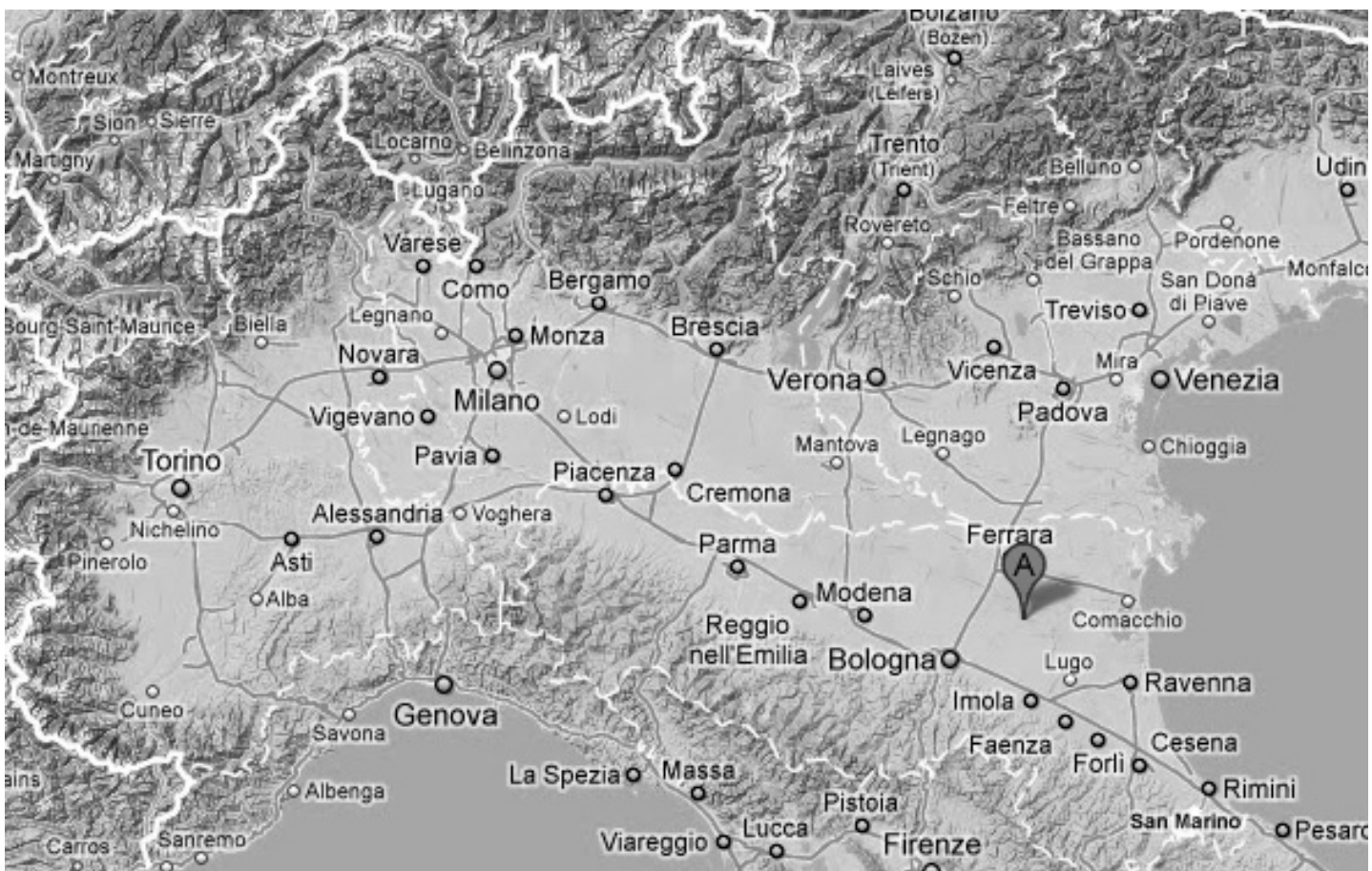

Fig. 1. Po Valley is bordered by the Alps to the north and west, by the forefront of Apennine Mountains to the south and the Adriatic Sea to the east. San Pietro Capofiume site (SPC) is marked with A on the map (sourced from Tele Atlas 2011).

and then to SPC. On 10 July, precipitating systems appeared in the eastern Po Valley with heavy rain in SPC. During these days, the boundary layer meteorology followed a typical diurnal evolution for July in the Po Valley, characterised by a transition from a stable, shallow nocturnal surface layer to a $1500 \mathrm{~m}$ - thick convective mixing layer between 8:00 and 13:00 (Di Giuseppe et al., 2012).

\section{Results and discussion}

HGFs for the whole duration of the campaign are displayed in Fig. 2a where darker colours represent lower growth factors and black dots represent averaged HGF between all sizes per HTDMA scan. During the first part of the campaign (27 June 2009 to 5 July 2009), distinct diurnal variability and generally lower HGFs with minima during night-time were recorded, reaching less than 1.2 , increasing to 1.45 during daytime. The second part of the campaign (5-11 July 2009) shows less variability and higher general (averaged) HGF values, ranging from 1.25 to 1.4. During the last two days, the highest daytime HGF of $>1.5$ was achieved, but nighttime HGFs did not drop below 1.25.

Analysis of the aerosol hygroscopicity for the duration of the campaign allows one to distinguish several periods:

- A (28 June - 2 July) corresponds with the highest overall HGFs recorded along with the highest night-time HGFs.
- B (2-4 July) shows the highest amplitude of diurnal variability of HGF with the lowest recorded night-time HGFs.

- C (5-6 July) can be described best as a transitory between two distinct periods. It was characterised by a high HGF variability.

- D (7-9 July, midday) exhibited the lowest amplitude of the HGF diurnal variation for the campaign.

- E (9 July, afternoon - 11 July) was characterised again by a clear diurnal pattern of HGF with moderate amplitude between day and night.

- G (12 July) again exhibited very high daytime HGFs while night-time HGFs remained moderately high.

The average diurnal variation of HGF for the duration of the campaign is shown in Fig. 2b. HGF is interpolated between the five measured sizes to give an overall picture of variation both in size and time. The lowest HGFs occurred in the early hours of morning (03:00-06:00), but, generally, the whole night shows very low hygroscopicity, particularly in the smaller sizes. The HGF difference between the measured sizes was the biggest at night with HGF 1.18 recorded for the smallest sized particles $(35 \mathrm{~nm})$ and HGF 1.38 recorded for the largest sizes $(165 \mathrm{~nm})$. During the day, the HGF gradually increases to achieve maximum in the afternoon hours 12:00-15:00. Maximum HGFs achieved were 1.32 for $35 \mathrm{~nm}$ particles and 1.46 for $165 \mathrm{~nm}$ particles. 
a)

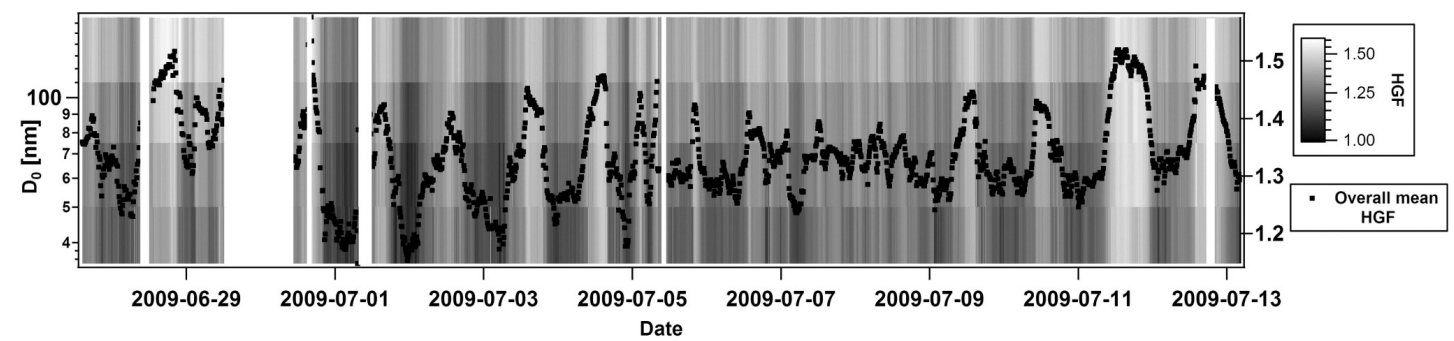

b)

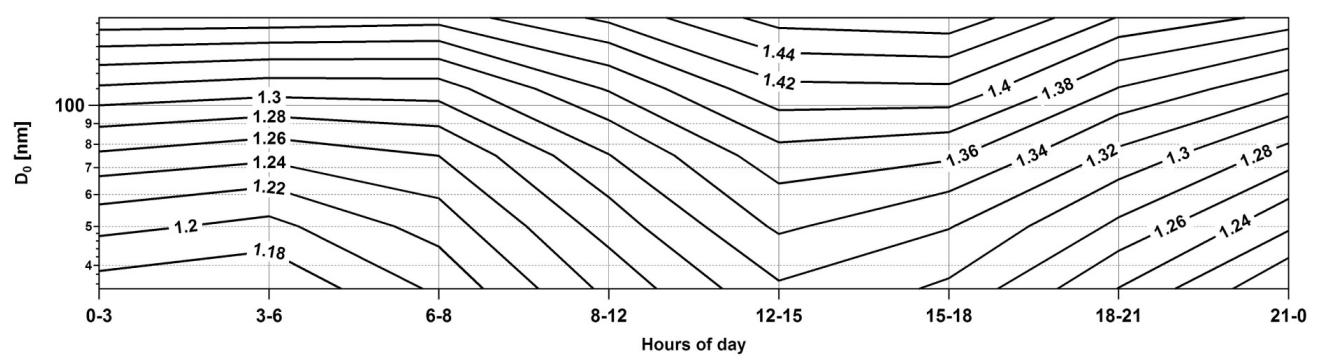

Fig. 2. (a) Size resolved HGF and mean HGF for whole duration of the campaign. (b) Size resolved diurnal variability of HGF for whole campaign.

\subsection{Diurnal variability - case studies}

Two clear types of diurnal patterns were evident and are chosen for more detailed analysis. One case type was characterised by low diurnal variability while the second case was characterised by a strong diurnal pattern. The HTDMA HGF probability distribution function was integrated to create four distinctive aerosol modes (Swietlicki et al., 2008): a barely hygroscopic fraction with HGF 1-1.12 (BH); a less hygroscopic fraction with HGF 1.125-1.34 (LH); a more hygroscopic fraction with HGF 1.345-1.87 (MH); and sea-salt-like fraction with HGF 1.875 and above (SS, not observed in this study).

\subsubsection{Case 1, period D: 7 July 2009 12:00 to 9 July 2009 12:00 (Fig. 3)}

Temperature started to rise from 05:00 and reached its maximum of $28^{\circ} \mathrm{C}$ around noon. The decrease was slowed down by the heat capacity of the ground and its long wave radiation back into the atmosphere. The minimum value of temperature, $19^{\circ} \mathrm{C}$, was recorded around 04:00. Westerly back trajectories during this period suggest advection of relatively fresher air masses (passing over the mountains). Total (AMS-derived) non-refractory aerosol mass concentrations peaked at $5 \mu \mathrm{g} \mathrm{m}^{-3}$ in the early afternoon, while minimum of $3 \mu \mathrm{g} \mathrm{m}^{-3}$ was achieved at midnight and shortly after sunrise. A diurnal pattern in the individual AMS mass components was not clearly visible either and very low nitrate mass level was observed (less than $0.1 \mu \mathrm{g} \mathrm{m}^{-3}$ throughout most of the day with a small peak of $0.7 \mu \mathrm{g} \mathrm{m}^{-3}$ around
20:00). During $24 \mathrm{~h}$, contributions of each AMS component were relatively stable with organics dominating the mass contribution, peaking at $2.5 \mu \mathrm{g} \mathrm{m}^{-3}$. In terms of percentage contribution to total AMS-derived mass, organics contributed $55 \%$, sulfate $30 \%$, ammonium $10 \%$ and nitrate $5 \%$. Organic concentration had three weak maxima during the day: $2.05 \mathrm{\mu g} \mathrm{m}^{-3}$ around 04:00, $2.55 \mu \mathrm{g} \mathrm{m}^{-3}$ at 14:00 and $2.5 \mu \mathrm{g} \mathrm{m}^{-3}$ at 19:00. The minimum for organics $\left(1.45 \mu \mathrm{g} \mathrm{m}^{-3}\right)$ was observed around 13:00. The sulfate maximum of $2 \mu \mathrm{g} \mathrm{m}^{-3}$ was recorded around 13:00, while the minimum of $0.6 \mu \mathrm{g} \mathrm{m}^{-3}$ was recorded at midnight. Ammonium's trend followed the one of sulfate. Ammonium's maximum of $0.7 \mu \mathrm{g} \mathrm{m}^{-3}$ was recorded at 13:00 while its minimum of $0.3 \mu \mathrm{g} \mathrm{m}^{-3}$ was recorded at midnight. The AMS PMF analysis reveals a HOA contribution of 5-20\% with peak contributions occurring at 07:00. COA contributes less than 5\% while OOA2 accounts for $20-45 \%$ and OOA 1 up to $40 \%$.

In terms of HGFs, the larger sized particles $(165 \mathrm{~nm})$ possess the highest HGFs with 75-80\% contributions from the MH GF and 5-20\% from BH HGFs. As smaller particles are considered, the MH HGF component progressively reduces to a $20-50 \%$ fraction of total particles in the $35 \mathrm{~nm}$ size range while the LH HGF component reduces to a fraction of 25$60 \%$. The minimum in growth factor occurs between 03:00 and 05:00, corresponding to a relative peak in the OGF of 1.13. The HTDMA minimum was recorded around 03:00 and the OTDMA maximum around 05:00. Both occur at low temperature close to temperature minimum at 04:00 when total organics and nitrate showed their highest values. Second and third peaks, both of the order of 1.125, are also seen at 10:00 


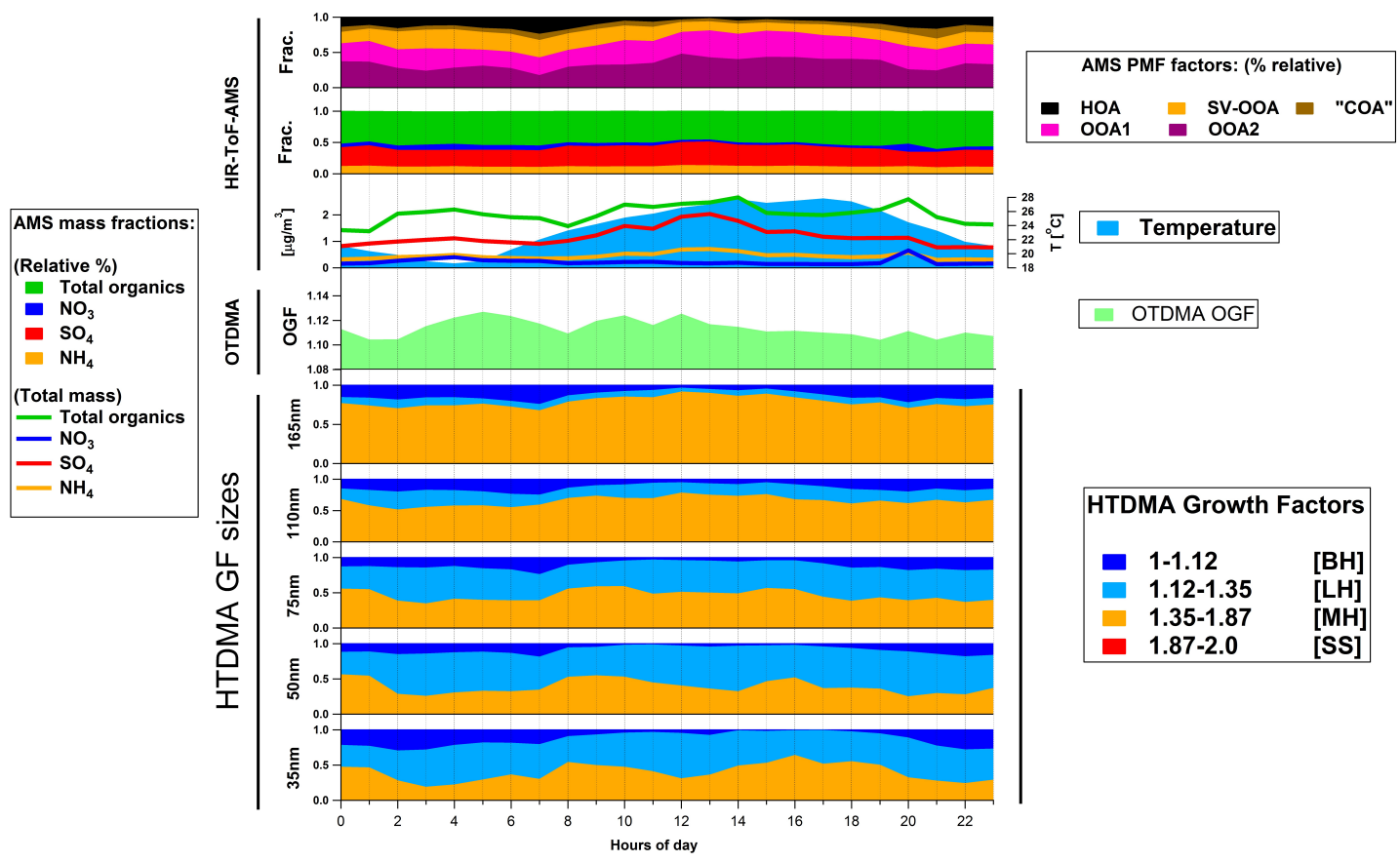

Fig. 3. From the top: diurnal pattern of relative PMF factors, main chemical compounds' mass fractions variation measured by the AMS, total mass (measured by the AMS) diurnal variation superimposed over the temperature, diurnal variation of the OGF and diurnal pattern of HGF groups (five panels describing HGF groups diurnal variation in sizes from 165 to $35 \mathrm{~nm}$ ). Note small variation of all the parameters, especially AMS mass fractions. More variation could be seen only in the PMF factors. Period: 7 July 2009 12:00 to 9 July 2009 12:00.

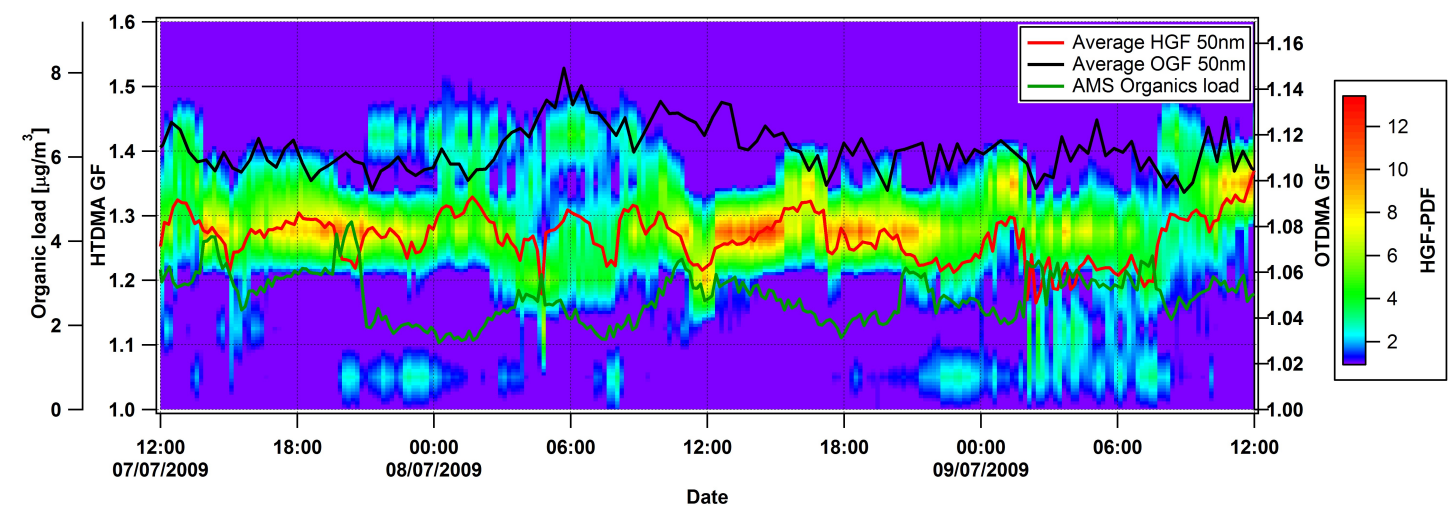

Fig. 4. Organic TDMA versus HTDMA and AMS organic load for Case 1 . The value of $50 \mathrm{~nm}$ was chosen as it was common for both instruments. Note that the OGF increased when moderately aged, regional (OOA2) aerosol was present, especially when HGF reached values of around 1.2.

and 12:00. The BH fraction of HGF tracks the HOA signal the closest. The OGF diurnal trend seems to be opposite to the AMS organic mass load diurnal variation.

A semi-volatile fraction (SV-OOA) is visible during the whole day in stable concentrations with only slightly higher contributions during the night. This fraction comes from partial oxidation of organics and is represented well by diurnal variations of the LH HGF group in a $110 \mathrm{~nm}$ particle size range. It is also worth mentioning that so called "Cooking Aerosol" (COA) factor concentration is steadily increasing from around 18:00. At the same time, the OGF's diurnal pattern is similar to SV-OOA (particularly in late night/early morning) and OOA1 (later during the day and in the evening).

The average $50 \mathrm{~nm}$ OGF and HGF are plotted with the total AMS organic mass and the HGF PDF in Fig. 4 where OGF increases when moderately aged, and regional (OOA2) aerosol is also increasing (Fig. 3), especially when HGF reaches values of around 1.2. However, this trend is not always apparent because other aerosol groups might have 


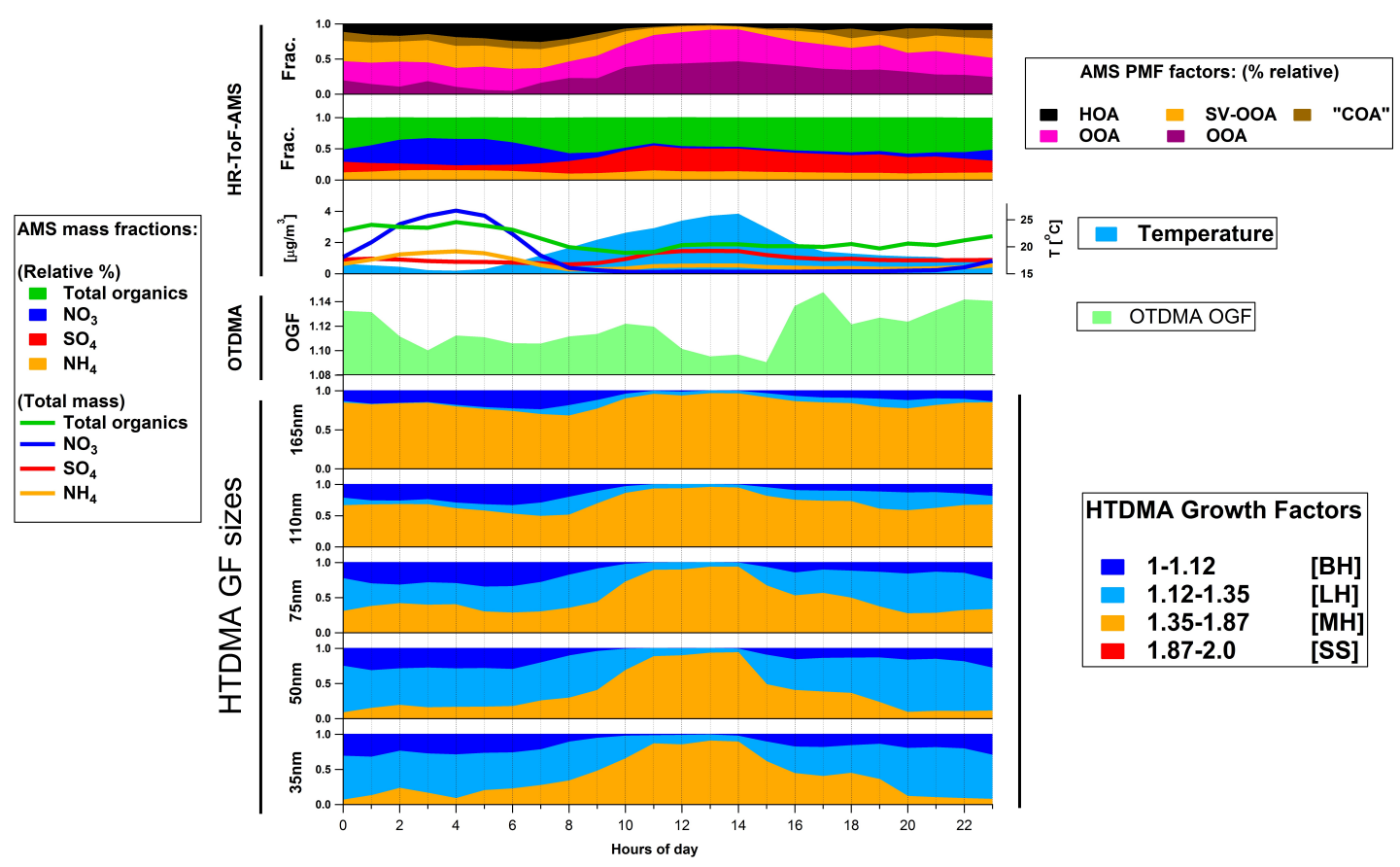

Fig. 5. From the top: diurnal pattern of relative PMF factors, main chemical compounds' mass fractions variation measured by the AMS, total mass (measured by the AMS) diurnal variation superimposed over the temperature, diurnal variation of the OGF and the diurnal pattern of HGF groups (five panels describing HGF groups diurnal variation in sizes from 165 to $35 \mathrm{~nm}$ ). Note the marked variation of the hygroscopic groups in sizes of 35-75 nm and less distinct variations in the size range 110-165 nm. Variations follow changes in the chemical composition of the aerosol. Period: 9 July 2009 12:00 to 11 July 2009 12:00.

similar impact on the OGF. The PDF illustrates a predominant HGF mode between 1.25 and 1.35 throughout the period, with two additional GF modes, one at 1.45 and one at 1.05 , occurring at night-time.

\subsubsection{Case 2, period E: 9 July 2009 12:00 to 11 July 2009 12:00 (Fig. 5)}

For this case, temperature was initially quite similar to Case 1 increasing from 05:00 and peaking around noon. In the afternoon, fast development of convective clouds caused the overcast and the temperature decreased. This was further accelerated by rain showers. A maximum of $26^{\circ} \mathrm{C}$ was recorded around 14:00, and a minimum of $15^{\circ} \mathrm{C}$ was recorded at 04:00. In contrast to Case 1, much higher levels of aerosol pollution were observed with peak concentrations of AMS-derived non-refractory mass exceeding $9 \mu \mathrm{g} \mathrm{m} \mathrm{m}^{-3}$ around 04:00, reducing to $\sim 3 \mu \mathrm{g} \mathrm{m}^{-3}$ at $09: 00-10: 00$. This reduction may be caused by deepening of the boundary layer and increased mixing height, thus greater dilution of bulk aerosol may occur. A daytime peak of $\sim 4 \mu \mathrm{g} \mathrm{m}^{-3}$ is seen at 13:00. The strong diurnal signal is driven by the nitrate temporal trend, but is also notably influenced by the organic contribution.

Nitrate mass ranged from $4 \mu \mathrm{g} \mathrm{m}^{-3}$ at 04:00 to less than $0.1 \mu \mathrm{g} \mathrm{m}^{-3}$ throughout the rest of the day. Total organic concentration was the highest during night-time and its maxi- mum $\left(3.2 \mu \mathrm{g} \mathrm{m}^{-3}\right)$ also corresponds with the high concentration of nitrate, occurring around 04:00 (see also Fig. 8). Minimum concentration of organics was recorded around 10:00 and slowly increased thereafter. Sulfate followed a different, flatter pattern with a minimum of $0.7 \mu \mathrm{g} \mathrm{m}^{-3}$ around 08:00 and maximum of $1.5 \mu \mathrm{g} \mathrm{m}^{-3}$ around noon. Ammonium exhibited two maxima accordingly to nitrate and sulfate maxima ranging from $1.5 \mu \mathrm{g} \mathrm{m}^{-3}$ at 04:00 to its minimum of $0.3 \mu \mathrm{g} \mathrm{m}^{-3}$ at 08:00. The AMS organic factor time trends (Fig. 5) show that the HOA accumulation was quite pronounced after midnight and was accelerated during the morning rush hour period. However, there is no evidence of the evening rush hour in the HOA diurnal cycle. This factor probably contributes to the HGF mode variability, as the BH fraction follows closely HOA's diurnal pattern in all measured sizes. It is also possible that COA, whose concentration increased from around 17:00 and remained stable during the night, also contributed to the build-up of the externally mixed BH mode in evening/night hours. The SV-OOA factor concentration started to increase from around 14:00 and reached a maximum around midnight. The variability of SVOOA seems the most strictly related to the diurnal changes in the LH particle concentrations. In particular, the diurnal evolution of LH follows SV-OOA very closely in the small particle $(35-75 \mathrm{~nm})$ size range. 


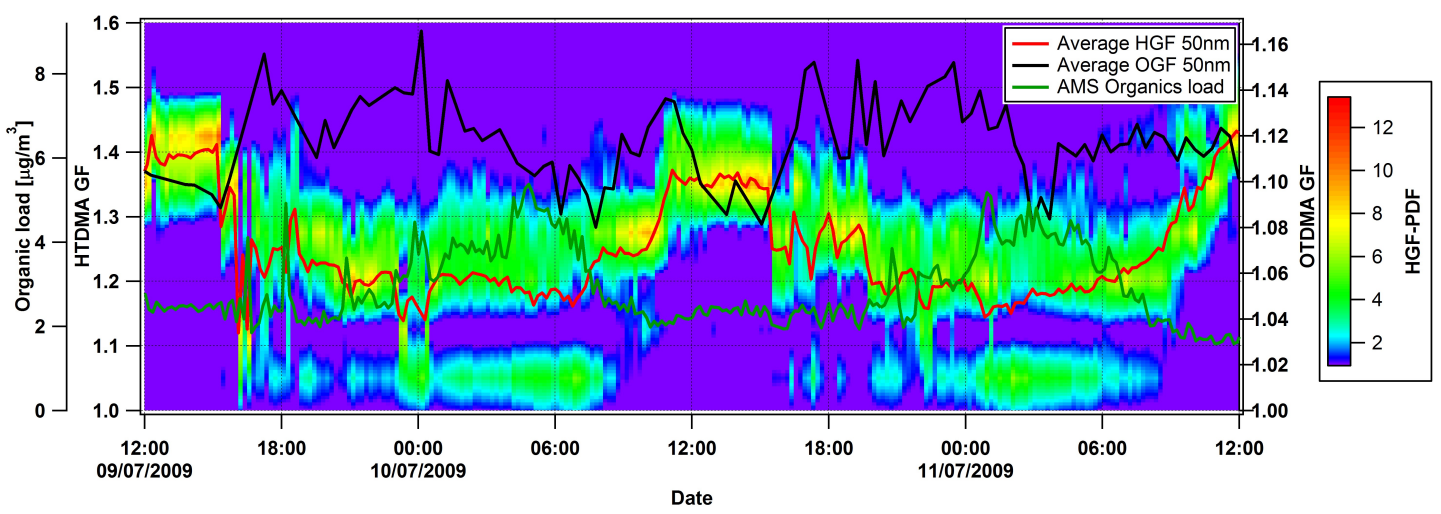

Fig. 6. Organic TDMA versus HTDMA and AMS total organic load for Case 2. The value of $50 \mathrm{~nm}$ was chosen as it was in common for both instruments. Note that while the AMS organic mass reached a maximum (between midnight and early morning) the OGF values decreased.

The MH fraction of HGFs exhibited higher diurnal variability in size range from 35 to $75 \mathrm{~nm}$ than from 110 to $165 \mathrm{~nm}$. For larger particle sizes of 110 and $165 \mathrm{~nm}$ a less strong diurnal pattern was seen, with an overall maximum through all sizes recorded around noon. The MH particles seem to be associated mainly with ammonium sulfate and $\mathrm{OO} 1$ and OOA2 organic aerosols. Interestingly, two minima were also recorded in the $\mathrm{MH}$ fraction: in late evening and again in the morning hours.

The diurnal cycle of OGFs was more complicated than that of HGFs. However, a clear OGF minimum of 1.09 was seen in the mid-afternoon. This minimum was related to the increase of sulfate, OOA1 and OOA2. The minimum is somewhat delayed with respect to the maximum in hygroscopicity. It is possible the accumulation of highly oxidised photochemical products, including not only inorganic sulfates and carboxylic acids, but also organosulfates, contributed to suppress the ethanol affinity of the particles after midday. In fact, organic compounds like organosulfates were shown to exhibit very low OGFs (Vaattovaara et al., 2009). The early afternoon HGF minimum was followed rapidly by an OGF peak of 1.15 at 17:00, which accompanied a weather change (see Sect. 4.1.2) with a sharp decrease in temperature (from 26 to $19^{\circ} \mathrm{C}$ ). The consequent condensation of semi-volatile organics (SV-OOA) traced by the AMS can explain the simultaneous increase in OGF. Another OGF peak of $1.14 \mathrm{oc}-$ curred just before midnight due to an additional increase of the SV-OOA fraction. Overall, aerosol affinity to ethanol is higher during the late afternoon and night hours as compared to the rest of the day. The minima in the OGF seem to anticorrelate with the MH HGF fraction for sizes $35-110 \mathrm{~nm}$.

Figure 6 shows that the hours of the day when the AMS organic mass reaches a maximum (between midnight and early morning) are characterised by decreasing OGF values, while HGFs remained steadily low. The rise in non-refractory aerosol mass concentrations in the second part of the night is certainly triggered by the increase in nitrate mass. The accumulation of nitrate-containing aerosols at night-time cannot be easily reconciled with the low hygroscopicity values observed by the HTDMA. It is worth noting that the 35 and $50 \mathrm{~nm}$ HGF values (i.e. Aitken mode size particles) are indeed low but the 110 and $165 \mathrm{~nm}$ HGF values (accumulation mode size particles) are in fact high at night (Fig. 5). Clearly, highly hygroscopic nitrates (i.e. ammonium nitrate) dominate in the accumulation mode sizes, not in the smaller size ranges. Several hypotheses can be made on the nature of such "low hygroscopicity nitrates" in the Aitken mode sizes: (a) that coating is done by poorly hygroscopic organic compounds, and (b) that the actual chemical nature of nitrate in Aitken mode particles is organic (e.g. nitrate esters), which is consistent with the decrease of OGFs observed between midnight and $\sim 06: 00$. In fact, in previous experiments (Vaattovaara et al., 2009) it was found that OGFs of particulate organic matter decrease in high $\mathrm{NO}_{\mathrm{x}}$ conditions and the ethanol affinity of organonitrate is apparently lower than that of the SV-OOA components forming in low- $\mathrm{NO}_{\mathrm{x}}$ conditions. Therefore, our hypothesis of the organonitrate formation provides an explanation for both the low HGFs and also the lowering of OGFs in the late night hours. Generally, the formation of organonitrates is expected to be probable, especially in the environment with a high load of $\mathrm{NO}_{\mathrm{x}}, \mathrm{NO}_{\mathrm{y}}$ and organics. Typically, that kind of high load conditions are observed during night-time at the SPC station. Importantly, $\mathrm{NO}_{3}$-initiated oxidation chemistry with alkenes is able to form organonitrates at night (e.g. Atkinson et al., 2000), i.e. without sunlight. Additional data supporting the organonitrate hypothesis using the ATOFMS (aerosol time-of-flight mass Spectrometer) is included in the supplementary materials.

Figure 7 shows time-slice PDFs extracted for each of the HGF sizes at 04:00-05:00 (i.e. the nitrate peak, total mass peak, and HGF minimum) and at 12:00-13:00 (the OGF minimum and HGF peak), while Fig. 8 shows AMS nitrate mass concentration for both morning and noontime periods. While not being quantitatively reliable, careful calculation of number concentration of particles from AMS mass concentration 


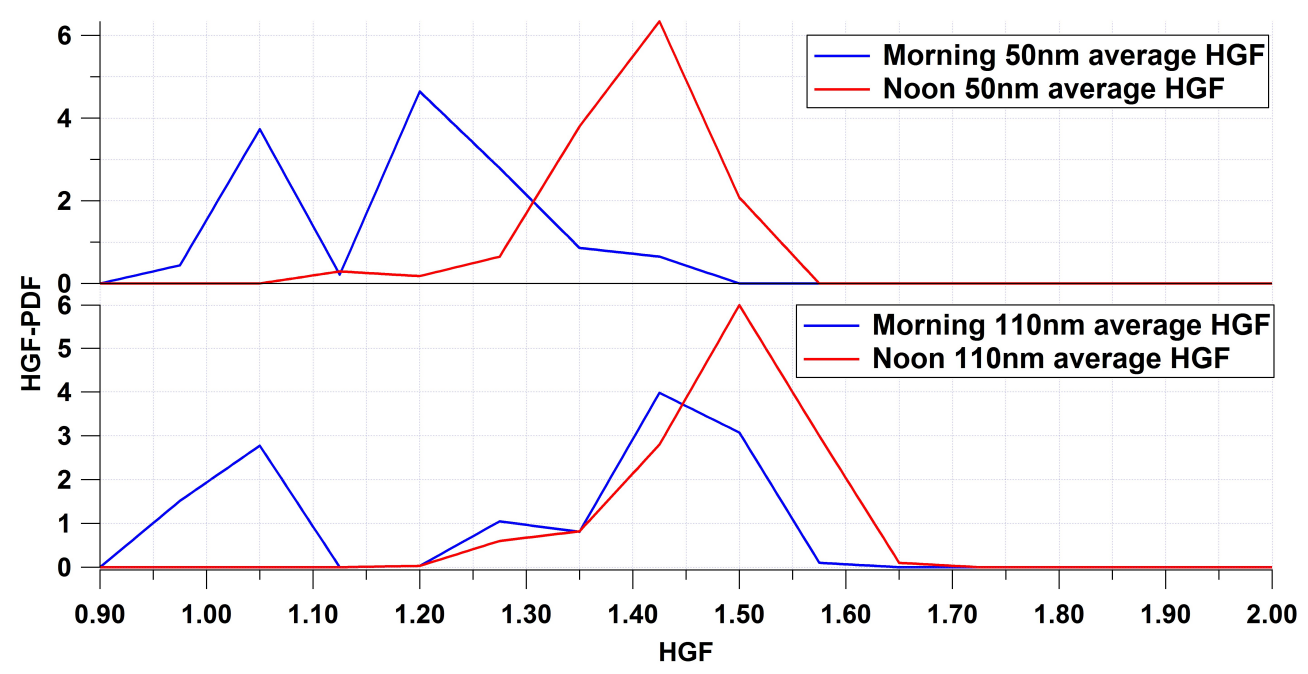

Fig. 7. HGF-PDF time slices for the morning average period (04:00-05:00) and the noon average period (12:00-13:00) of average HGF for 50 and $110 \mathrm{~nm}$ sized particles for Case 2. The shift toward higher HGFs during the day was more pronounced in the smaller size range.

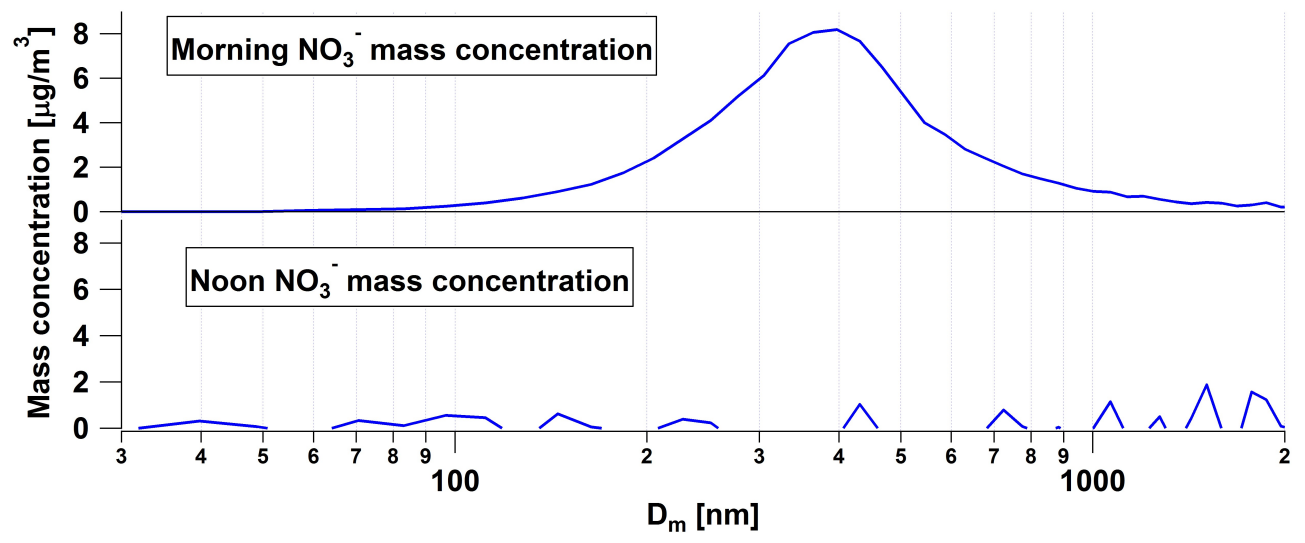

Fig. 8. AMS size-segregated mass distribution of nitrates $\left(\mathrm{NO}^{3-}\right)$ for the morning average period (04:00-05:00) and the noon average period (12:00-13:00) of the Case 2. During the day the nitrate group disappeared. The mass peak was centred at $350 \mathrm{~nm}$ and thus easily detectable by the AMS.

can give a rough idea of size regimes in which both AMS and HTDMA overlap. Analysis of nitrate number distribution in mobility equivalent diameter (Fig. 9) reveals that the majority of particles are represented by the $50-110 \mathrm{~nm}$ size range, which overlaps both HTDMA and OTDMA measurement regimes. The number concentration was calculated using a simple equation:

$N=\mathrm{MNO}_{3} \cdot 6 /\left(1.72 \cdot \pi \mathrm{Dm}^{3}\right)$,

where $N$ is a number concentration $\left(\mathrm{cm}^{-3}\right), \mathrm{MNO}_{3}$ is a mass concentration of nitrate measured by the $\operatorname{AMS}\left(\mu \mathrm{g} \mathrm{m}^{-3}\right)$, 1.72 is the assumed density of the nitrate spherical particle $\left(\mathrm{g} \mathrm{m}^{-3}\right)$ and Dm is the diameter of the particle $(\mathrm{nm})$.

For $50 \mathrm{~nm}$ particles, during the nitrate peak, two strong HGF modes are seen at 1.04 and 1.2, with a third, less pronounced peak at 1.36. This stands in contrast to the noontime predominant single peak at 1.44 and a significantly less evi- dent HGF mode at 1.14. For $110 \mathrm{~nm}$ sized particles, the HGF PDF during the nitrate peak is again tri-modal, with a primary mode at 1.4 , a secondary mode at 1.04 , and a third, minor, peak at 1.26. This is in contrast to the noontime primary peak of 1.5 and secondary minor peak of 1.26 . If we compare the results obtained at night to those during midday, we conclude that (1) there is a notable reduction in the HGF associated with the MH mode, with a reduction in HGF from $\sim 1.5$ to $\sim 1.26$; and (2) there is the appearance of at least one (externally mixed) $\mathrm{BH}$ mode.

\section{Conclusions}

A HTDMA, OTDMA and AMS were deployed in the Po Valley's San Pietro Capofiume research station to characterise water and ethanol uptake by the aerosol associated 


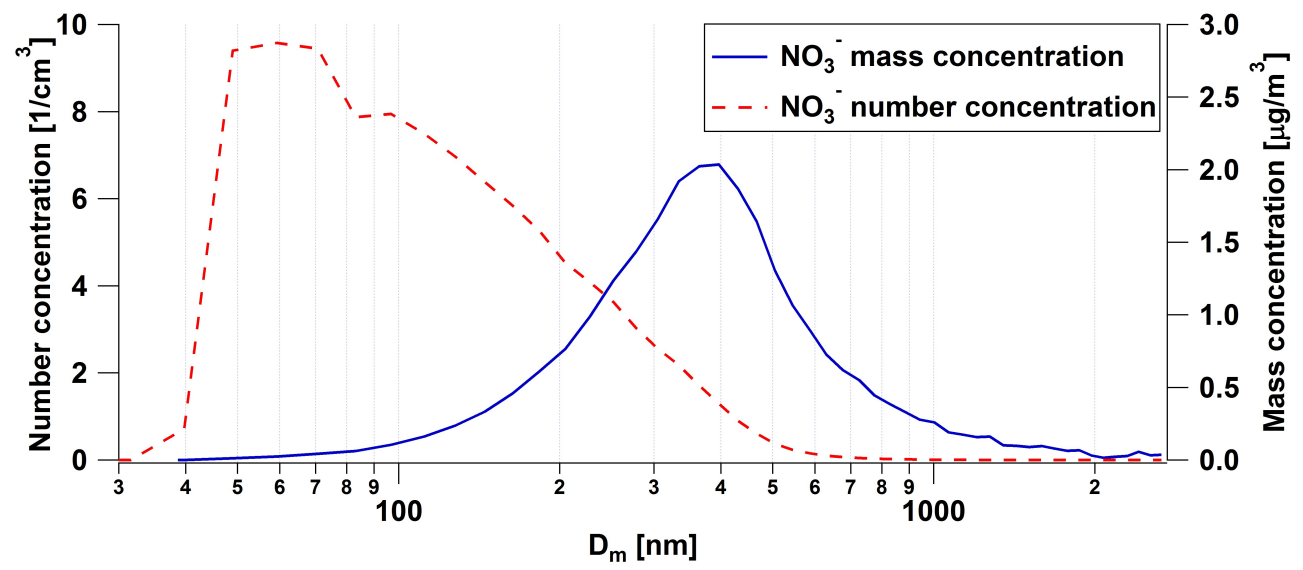

Fig. 9. AMS size segregated mass and number concentration of nitrates $\left(\mathrm{NO}^{3-}\right)$ for Case 2. Note that the number size concentration peaked around $50-60 \mathrm{~nm}$, while the mass concentration exhibited its peak around $350 \mathrm{~nm}$. Both AMS and HTDMA/OTDMA can reliably sample and measure relevant aerosol properties. Total concentration of nitrate particles calculated: $1798 \mathrm{~cm}^{-3}$.

with polluted continental air and how these properties are influenced by the aerosol chemical composition. The average diurnal variation of HGF for the duration of the campaign revealed the lowest HGFs occurring in early morning hours (03:00-06:00) and in the smallest sizes. The average HGFs recorded during the low HGF period were in the range from 1.18 (for the smallest, $35 \mathrm{~nm}$ particles) to 1.38 (for the largest, $165 \mathrm{~nm}$ particles). During the day, the HGF gradually increased to achieve maximum values in the early afternoon hours from 12:00 to 15:00, reaching 1.32 for $35 \mathrm{~nm}$ particles and 1.46 for $165 \mathrm{~nm}$ particles.

Two cases were examined in close detail in terms of the influence of chemical composition on HGF. One case type was characterised by moderate levels of pollution and with organic matter dominating the aerosol mass. This case illustrated little diurnal variability in relative contributions of different aerosol types, HGF, or OGF. The most distinctive pattern was seen in the reduction in the MH mode from approximately $80 \%$ in $165 \mathrm{~nm}$ sized particles to $20-40 \%$ in $35 \mathrm{~nm}$ sized particles, while the LH mode contribution increased from less than $5 \%$ to more than $30 \%$ over the same size range. For this case, organic mass contributed approximately $50 \%$ of the total non-refractory mass. OGF values followed the trends of the less oxidised OOAs, especially the SV-OOA. In contrast to Case 1, the second selected case had more than double the aerosol mass and exhibited a strong diurnal pattern, particularly for nitrates and also for organic mass, both of which peaked in the early morning as peak mass concentration exceeded $9.5 \mu \mathrm{g} \mathrm{m}^{-3}$. Particularly in the smallest sized particles, a strong diurnal signal was seen in the HGFs with peak HGFs occurring around noon and minima occurring around midnight. Despite nitrate mass peaking at $4 \mu \mathrm{g} \mathrm{m}^{-3}$ around 04:00, the MH HGF reached its minimum value and both the $\mathrm{BH}$ and $\mathrm{LH}$ factors reached their maximum values. OGFs were anti-correlated with HGFs most of the time, as to be expected because very hydrophilic com- pounds such as ammonium sulfate and much oxidised organic compounds have poor ethanol affinity. However, in late night/early morning hours, OGFs decreased and the HGFs were steadily low. The OGF and HGF results for this time of the day cannot be easily reconciled with the AMS chemical composition; as OGFs are low despite the moderately oxidised SV-OOA are high, and the HGFs are low while nitrate aerosols peak in concentrations. We hypothesise that low-hygroscopicity nitrate compounds, specifically organic nitrates, form in late night hours leading to a decrease in the ethanol affinity of SV-OOA while keeping low the hygroscopicity in small particles.

As a last finding of the HGF-PDF analysis, it was shown that an externally mixed BH mode appeared at night, which is consistent with the accumulation of primary combustion particles, which most likely correspond to the AMS organic factors of HOA and COA ("cooking aerosols").

\section{Supplementary material related to this article is available online at http://www.atmos-chem-phys.net/14/ 1557/2014/acp-14-1557-2014-supplement.pdf.}

Acknowledgements. This work was supported by the FP6 EUCAARI Integrated Project, Ireland's Higher Education Authority Programme for Research in Third Level Institutes (4), project Environment and Climate: Impact and Responses, and the Centre of Excellence of the Finnish Academy.

Edited by: B. Ervens 


\section{References}

Allan, J. D., Williams, P. I., Morgan, W. T., Martin, C. L., Flynn, M. J., Lee, J., Nemitz, E., Phillips, G. J., Gallagher, M. W., and Coe, H.: Contributions from transport, solid fuel burning and cooking to primary organic aerosols in two UK cities, Atmos. Chem. Phys., 10, 647-668, doi:10.5194/acp-10-647-2010, 2010.

Ansari, A. S. and Pandis, S. N.: Prediction of multicomponent inorganic atmospheric aerosol behavior, Atmos. Environ., 33, 745757, 1999.

Anttila, T., Vaattovaara, P., Komppula, M., Hyvärinen, A.-P., Lihavainen, H., Kerminen, V.-M., and Laaksonen, A.: Sizedependent activation of aerosols into cloud droplets at a subarctic background site during the second Pallas Cloud Experiment (2nd PaCE): method development and data evaluation, Atmos. Chem. Phys., 9, 4841-4854, doi:10.5194/acp-9-4841-2009, 2009.

Atkinson, R., Calvert, J. G., Kerr, J. A., Madronich, S., Moortgat, G. K., Wallington, T. J., and Yarwood. G.: The mechanism of Atmospheric Oxidation of the Alkenes, Oxford Univ. Press., Oxford, UK, 172-335, 2000.

Baltensperger, U., Kalberer, M., Dommen, J., Paulsen, D., Alfarra, M. R., Coe, H., Fisseha, R., Gascho, A., Gysel, M., Nyeki, S., Sax, M., Steinbacher, M., Prévôt, A. S. H., Sjøgren, S., Weingartner, E., and Zenobi, R.: Secondary organic aerosols from anthropogenic and biogenic precursors. Faraday Discuss., 130, 265-278, 2005.

Boy, M., Petäjä, T., Dal Maso, M., Rannik, Ü., Rinne, J., Aalto, P., Laaksonen, A., Vaattovaara, P., Joutsensaari, J., Hoffmann, T., Warnke, J., Apostolaki, M., Stephanou, E. G., Tsapakis, M., Kouvarakis, A., Pio, C., Carvalho, A., Römpp, A., Moortgat, G., Spirig, C., Guenther, A., Greenberg, J., Ciccioli, P., Kulmala, M.: Overview of the field measurement campaign in Hyytiälä, August 2001 in the framework of the EU project OSOA, Atmos. Chem. Phys., 4, 657-678, doi:10.5194/acp-4-657-2004, 2004.

Canagaratna, M. R., Jayne, J. T., Ghertner, D. A., Herndon, S., Shi, Q., Jimenez, J. L., Silva, P. J., Williams, P., Lanni, T., Drewnick, F., Demerjian, K. L., Kolb, C. E., and Worsnop, D. R.: Chemical and microphysical characterization of aerosols via Aerosol Mass Spectrometry, Mass Spectrom. Rev., 26, 185-222, 2007.

Dall'Osto, M., Beddows, D.C.S., Pey, J., Rodriguez, S., Alastuey, A., Harrison, Roy M., and Querol, X.: Urban aerosol size distributions over the Mediterranean city of Barcelona, NE Spain, Atmos. Chem. Phys., 12, 10693-10707, doi:10.5194/acp-1210693-2012, 2012.

Dennis, W. L.: The growth of hygroscopic drops in a humid air stream. Discussions of the Faraday Society, 30, 78-85, 1960.

Di Giuseppe, F., A. Riccio, L. Caporaso, G. Bonafé, G. P. Gobbi and F.Angelini, 2012. "Automatic detection of atmospheric boundary layer height using ceilometer backscatter data assisted by a boundary layer model", Q. J. R. Meteorol. Soc. 138: 649-663.

Duplissy, J., DeCarlo, P. F., Dommen, J., Alfarra, M. R., Metzger, A., Barmpadimos, I., Prevot, A. S. H., Weingartner, E., Tritscher, T., Gysel, M., Aiken, A. C., Jimenez, J. L., Canagaratna, M. R., Worsnop, D. R., Collins, D. R., Tomlinson, J., and Baltensperger, U.: Relating hygroscopicity and composition of organic aerosol particulate matter, Atmos. Chem. Phys., 11, 11551165, doi:10.5194/acp-11-1155-2011, 2011.

Gasparini, R., Li, R., and Collins, D. R.: Integration of size distributions and size-resolved hygroscopicity measured during the Houston Supersite for compositional categorization of the aerosol, Atmos. Environ., 38, 3285-3303, 2004.

Gysel, M., McFiggans, G. B., and Coe, H.: Inversion of tandem differential mobility analyser (TDMA) measurements, J. Aerosol Sci., 40, 134-151, 2009.

Gysel, M., Weingartner, E., Nyeki, S., Paulsen, D., Baltensperger, U., Galambos, I., and Kiss, G.: Hygroscopic properties of watersoluble matter and humic-like organics in atmospheric fine aerosol, Atmos. Chem. Phys., 4, 35-50, doi:10.5194/acp-4-352004, 2004.

Hänel, G. . The Properties of Atmospheric Aerosol Particles as Functions of the Relative Humidity at Thermodynamic Equilibrium with the Surrounding Moist Air, Academic Press Inc., Adv. Geophys., 19, 73-188, 1976.

Hegg, D., Larson, T., and Po-Fat, Y.: A theoretical study of the effect of relative humidity on light scattering by tropospheric aerosols, J. Geophys. Res., 98, 18435-18439, 1993.

Jayne, T. J., leard, C. D., zhang, X., Davidovits, P., Smith, A. K., Kolb, E. C., and Worsnop, R. D.: Development of an aerosol mass spectrometer for size and composition analysis of submicron particles, Taylor and Francis, Colchester, Royaume-Uni, 50-70, 2000

Jimenez, J. L., Canagaratna, M. R., Donahue, N. M., Prévôt, A. S. H., Zhang, Q., Kroll, J. H., DeCarlo, P. F., Allan, J. D., Coe, H., Ng, N. L., Aiken, A.C., Docherty, K. S., Ulbrich, I. M., Grieshop, A.P., Robinson, A. L., Duplissy, J., Smith, J. D., Wilson, K. R., Lanz, V. A., Hueglin, C., Sun, Y. L., Tian, J., Laaksonen, A., Raatikainen, T., Rautiainen, J., Vaattovaara, P., Ehn, M., Kulmala, M., Tomlinson, J. M., Collins, D. R., Cubison, M. J., Dunlea, E.J., Huffman, J. A., Onasch, T. B., Alfarra, M. R., Williams, P. I., Bower, K., Kondo, Y., Schneider, J., Drewnick, F., Borrmann, S., Weimer, S., Demerjian, K., Salcedo, D., Cottrell, L., Griffin, R., Takami, A., Miyoshi, T., Hatakeyama, S., Shimono, A., Sun, J. Y., Zhang, Y. M., Dzepina, K., Kimmel, J. R., Sueper, D., Jayne, J. T., Herndon, S. C., Trimborn, A. M., Williams, L. R., Wood, E. C., Middlebrook, A. M., Kolb, C. E., Baltensperger, U., and Worsnop, D. R.: Evolution of organic aerosols in the atmosphere, Science, 326, 1525-1529, 2009.

Jimenez, J. L., DeCarlo, P. F., Kimmel, J. R., Trimborn, A., Northway, M. J., Jayne, J. T., Aiken, A. C., Gonin, M., Fuhrer, K., Horvath, T., Docherty, K. S., and Worsnop, D. R.. Field-deployable, high-resolution, time-of-flight aerosol mass spectrometer, Anal. Chem., 78, 8281-8289, 2006.

Jimenez, J .L., Jayne, J. T., Shi, Q., Kolb, C. E., Worsnop, D. R., Yourshaw, I., Seinfeld, J. H., Flagan, R. C., Zhang, X., Smith, K. A., Morris, J. W., and Davidovits, P.: Ambient aerosol sampling using the Aerodyne Aerosol Mass Spectrometer, J. Geophys. Res. D Atmos., 108, SOS 13-1-SOS 13-13, 2003.

Jones, H. M., Crosier, J., Russell, A., Flynn, M. J., Irwin, M., Choularton, T. W., Coe, H., and McFiggans, G.: In situ aerosol measurements taken during the 2007 COPS field campaign at the Hornisgrinde ground site, Q. J. Roy. Meteorol. Soc., 137, 252 266, 2011.

Joutsensaari, J., Vaattovaara, P., Vesterinen, M., Hämeri, K., and Laaksonen, A.: A novel tandem differential mobility analyzer with organic vapor treatment of aerosol particles, Atmos. Chem. Phys., 1, 51-60, doi:10.5194/acp-1-51-2001, 2001.

Jurányi, Z., Gysel, M., Weingartner, E., Decarlo, P. F., Kammermann, L., Baltensperger, U.: Measured and modelled 
cloud condensation nuclei number concentration at the high alpine site Jungfraujoch, Atmos. Chem. Phys., 10, 7891-7906, doi:10.5194/acp-10-7891-2010, 2010.

Kittelson, D. B.: Engines and nanoparticles: A review, J. Aerosol Sci., 29, 575-588, 1998.

Knutson, E. O. and Whitby, K. T.: Aerosol classification by electric mobility: apparatus, theory, and applications, J. Aerosol Sci., 6, 443-451, 1975.

Kupiainen, K. and Klimont, Z.: Primary emissions of fine carbonaceous particles in Europe, Atmos. Environ., 41, 2156-2170, 2007.

Lanz, V.A., Alfarra, M. R., Baltensperger, U., Buchmann, B., Hueglin, C., Prévôt, A. S. H.: Source apportionment of submicron organic aerosols at an urban site by factor analytical modelling of aerosol mass spectra, Atmos. Chem. Phys., 7, 15031522, doi:10.5194/acp-7-1503-2007, 2007.

Lee, E., Chan, C. K., Paatero, P.: Application of positive matrix factorization in source apportionment of particulate pollutants in Hong Kong, Atmos. Environ., 33, 3201-3212, 1999.

Liu, B. Y. H., Pui, D. Y. H., and Whitby, K. T.: The aerosol mobility chromatograph: a new detector for sulfuric acid aerosols. Atmos. Environ., 12, 99-104, 1978.

Massoli, P., Lambe, A. T., Ahern, A. T., Williams, L. R., Ehn, M., Mikkilä, J., Canagaratna, M. R., Brune, W. H., Onasch, T. B., Jayne, J. T., Petäjä, T., Kulmala, M., Laaksonen, A., Kolb, C. E., Davidovits, P., and Worsnop, D. R.: Relationship between aerosol oxidation level and hygroscopic properties of laboratory generated secondary organic aerosol (SOA) particles, Geophys. Res. Lett., 37, L24801, doi:10.1029/2010GL045258, 2011.

McFiggans, G., Artaxo, P., Baltensperger, U., Coe, H., Facchini, M. C., Feingold, G., Fuzzi, S., Gysel, M., Laaksonen, A., Lohmann, U., Mentel, T. F., Murphy, D. M., O’Dowd, C. D., Snider, J. R., and Weingartner, E.: The effect of physical and chemical aerosol properties on warm cloud droplet activation, Atmos. Chem. Phys., 6, 2593-2649, doi:10.5194/acp-6-2593-2006, 2006.

McInnes, L., Bergin, M., Ogren, J., and Schwartz, S.: Apportionment of light scattering and hygroscopic growth to aerosol composition. Geophys. Res. Lett., 25, 513-516, 1998.

Meyer, N. K., Duplissy, J., Gysel, M., Metzger, A., Dommen, J., Weingartner, E., Alfarra, M. R., Prevot, A. S. H., Fletcher, C., Good, N., McFiggans, G., Jonsson, A. M., Hallquist, M., Baltensperger, U., and Ristovski, Z. D.: Analysis of the hygroscopic and volatile properties of ammonium sulphate seeded and unseeded SOA particles, Atmos. Chem. Phys., 9, 721-732, doi:10.5194/acp-9-721-2009, 2009.

Middlebrook, A. M., Bahreini, R., Jimenez, J. L., and Canagaratna, M. R.: Evaluation of Composition-Dependent Collection Efficiencies for the Aerodyne Aerosol Mass Spectrometer using Field Data, Aerosol Sci. Technol., 46, 258-271, doi:10.1080/02786826.2011.620041, 2012.

Mochida, M. and Kawamura, K.: Hygroscopic properties of levoglucosan and related organic compounds characteristic to biomass burning aerosol particles, J. Geophys. Res. D Atmos., 109, 1-8, 2004.

Mochida, M., Miyakawa, T., Takegawa, N., Morino, Y., Kawamura, K., and Kondo, Y.: Significant alteration in the hygroscopic properties of urban aerosol particles by the secondary formation of organics, Geophys. Res. Lett., 35, L02804, doi:10.1029/2007GL031310, 2008.
Ng, N. L., Kroll, J. H., Keywood, M. D., Bahreini, R., Varutbangkul, V., Flagan, R. C., Seinfeld, J. H., Lee, A., and Goldstein, A. H.: Contribution of first- versus second-generation products to secondary organic aerosols formed in the oxidation of biogenic hydrocarbons, Environ. Sci. Technol., 40, 2283-2297, 2006.

Paatero, P. and Tapper, U.: Positive matrix factorization: a nonnegative factor model with optimal utilization of error estimates of data values, Environmetrics, 5, 111-126, 1994.

Petäjä, T., Kerminen, V. M., Hämeri, K., Vaattovaara, P., Joutsensaari, J., Junkermann, W., Laaksonen, A., Kulmala, M.. Effects of SO 2 oxidation on ambient aerosol growth in water and ethanol vapours, Atmos. Chem. Phys., 5, 767-779, doi:10.5194/acp-5767-2005, 2005.

Raatikainen, T., Vaattovaara, P., Tiitta, P., Miettinen, P., Rautiainen, J., Ehn, M., Kulmala, M., Laaksonen, A., and Worsnop, D. R.: Physicochemical properties and origin of organic groups detected in boreal forest using an aerosol mass spectrometer, Atmos. Chem. Phys., 10, 2063-2077, doi:10.5194/acp-10-20632010, 2010.

Rogge, W. F., Hildemann, L. M., Mazurek, M. A., Cass, G. R., and Simoneit, B. R. T.: Sources of fine organic aerosol. 2. Noncatalyst and catalyst-equipped automobiles and heavy-duty diesel trucks, Environ. Sci. Technol., 27, 636-651, 1993.

Saxena, P., Hildemann, L. M., McMurry, P. H., and Seinfeld, J. H.: Organics alter hygroscopic behavior of atmospheric particles, J. Geophys. Res., 100, 18755-18770, 1995.

Schauer, J. J., Rogge, W. F., Hildemann, L. M., Mazurek, M. A., Cass, G. R., and Simoneit, B. R. T.: Source apportionment of airborne particulate matter using organic compounds as tracers, Atmos. Environ., 30, 3837-3855, 1996.

Svenningsson, B., Hansson, H. C., Wiedensohler, A., Noone, K., Ogren, J., Hallberg, A., and Colvile, R.: Hygroscopic growth of aerosol particles and its influence on nucleation scavenging in cloud: Experimental results from Kleiner Feldberg, J. Atmos. Chem., 19, 129-152, 1994.

Swietlicki, E., Hansson, H. C., Hämeri, K., Svenningsson, B., Massling, A., McFiggans, G., McMurry, P. H., Petäjä, T., Tunved, P., Gysel, M., Topping, D., Weingartner, E., Baltensperger, U., Rissler, J., Wiedensohler, A., and Kulmala, M.: Hygroscopic properties of submicrometer atmospheric aerosol particles measured with H-TDMA instruments in various environments - A review, Tellus B: Chem. Phys. Meteorol., 60, 432-469, 2008.

Tiitta, P., Miettinen, P., Vaattovaara, P., Joutsensaari, J., Petäjä, T., Virtanen, A., Raatikainen, T., Aalto, P., Portin, H., Romakkaniemi, S., Kokkola, H., Lehtinen, K. E. J., Kulmala, M., and Laaksonen, A.: Roadside aerosol study using hygroscopic, organic and volatility TDMAs: Characterization and mixing state, Atmos. Environ., 44, 976-986, 2010.

Ulbrich, I. M., Canagaratna, M. R., Zhang, Q., Worsnop, D. R., and Jimenez, J. L.: Interpretation of organic components from Positive Matrix Factorization of aerosol mass spectrometric data, Atmos. Chem. Phys., 9, 2891-2918, doi:10.5194/acp-9-2891-2009, 2009.

Vaattovaara, P., Petäjä, T., Joutsensaari, J., Miettinen, P., Zaprudin, B., Kortelainen, A., Heijari, J., Yli-Pirilä, P., Aalto, P., Worsnop, D. R., Laaksonen, A.. The evolution of nucleation- and Aitkenmode particle compositions in a boreal forest environment during clean and pollution-affected new-particle formation events, Boreal Environ. Res., 14, 662-682, 2009. 
Vaattovaara, P., Räsänen, M., Kühn, T., Joutsensaari, and J., Laaksonen, A.: A method for detecting the presence of organic fraction in nucleation mode sized particles, Atmos. Chem. Phys., 5, 3277-3287, doi:10.5194/acp-5-3277-2005, 2005.

Varutbangkul, V., Brechtel, F. J., Bahreini, R., Ng, N. L., Keywood, M. D., Kroll, J. H., Flagan, R. C., Seinfeld, J. H., Lee, A., and Goldstein, A. H.: Hygroscopicity of secondary organic aerosols formed by oxidation of cycloalkenes, monoterpenes, sesquiterpenes, and related compounds, Atmos. Chem. Phys., 6, 23672388, doi:10.5194/acp-6-2367-2006, 2006.
Zhang, Q., Worsnop, D. R., Canagaratna, M. R., and Jimenez, J. L.: Hydrocarbon-like and oxygenated organic aerosols in Pittsburgh: insights into sources and processes of organic aerosols, Atmos. Chem. Phys., 5, 3289-3311, doi:10.5194/acp-5-32892005, 2005. 